\title{
Seroprevalence and risk factors for Neospora caninum in goats in Santa Catarina state, Brazil
}

Soroprevalência e fatores de risco para Neospora caninum em caprinos no estado Santa Catarina, Brasil

Josué Pires Topazio; ; Augusto Weber²; Giovana Camillo²; Fernanda Flores Vogel²; Gustavo Machado ${ }^{3}$; André Ribeiro ${ }^{4}$; Anderson Barbosa Moura ${ }^{4}$; Leandro Sâmia Lopes ${ }^{1}$; Alexandre Alberto Tonin²; Natan Marcos Soldá1; Patrícia Bräunig²; Aleksandro Schafer da Silva ${ }^{1 *}$

\author{
${ }^{1}$ Departamento de Zootecnia do Centro de Educação Superior do Oeste, Universidade do Estado de Santa Catarina - UDESC, \\ Chapecó, SC, Brasil \\ ${ }^{2}$ Departamento de Medicina Veterinária Preventiva, Universidade Federal de Santa Maria - UFSM, Santa Maria, RS, Brasil \\ ${ }^{3}$ Laboratório de Epidemiologia Veterinária - EPILAB, Faculdade de Veterinária - FAVET, Universidade Federal do Rio Grande do \\ Sul - UFRGS, Porto Alegre, RS, Brasil \\ ${ }^{4}$ Departamento de Medicina Veterinária, Centro de Ciências Agroveterinárias, Universidade do Estado de Santa Catarina - UDESC, \\ Lages, SC, Brasil
}

Received May 06, 2014

Accepted June 26, 2014

\begin{abstract}
Neosporosis is an infectious disease caused by the parasite Neospora caninum. Knowledge regarding neosporosis in goats is still quite limited, especially in the state of Santa Catarina (SC), southern Brazil. Therefore, this study aimed to assess the seroprevalence and risk factors for $N$. caninum in goats in the western and mountain regions of SC. Blood samples were collected from 654 goats in 57 municipalities. The indirect immunofluorescence test was used for antibody detection against $N$. caninum. Thirty samples (4.58\%) were seropositive, with titers ranging from 1:50 to 1:6400. An epidemiological survey was also conducted in order to identify risk factors for neosporosis in goats. It was found that reproductive problems on the farms, as well as the diet and direct contact with dogs were casual risks for neosporosis. These results indicate that $N$. caninum infects goats in these regions, which may lead to reproductive problems.
\end{abstract}

Keywords: Neosporosis, risk factors, reproductive problems, small ruminants.

\section{Resumo}

Neosporose é uma doença infecciosa causada pelo parasito Neospora caninum. Nos caprinos, as informaçôes sobre neosporose ainda são bastante limitadas, especialmente no Estado de Santa Catarina (SC), Sul do Brasil. Em virtude disso, este estudo teve como objetivo avaliar a soroprevalência e os fatores de risco envolvidos na infecção por $N$. caninum em caprinos das regióes Oeste e Planalto Serrano do Estado de SC. Amostras de sangue foram coletadas de 654 caprinos em 57 cidades. A técnica de imunofluorescência indireta (RIFI) foi usada para a detecçáo sorológica de anticorpos contra $N$. caninum. Trinta amostras $(4,58 \%)$ foram soropositivas para o agente infeccioso com títulos variando entre 1:50 a 1:6400. Durante a coleta de sangue, um levantamento epidemiológico foi realizado para identificar fatores de risco para neosporose em caprinos. Problemas reprodutivos presentes nas fazendas, bem como a dieta e o contato direto com cáes foram detectados como fatores de risco para a doença. Os resultados indicam que $N$. caninum infecta cabras nas regiōes avaliadas, o que pode estar relacionado a problemas reprodutivos nesta espécie.

Palavras-chave: Neosporose, fatores de risco, problemas reprodutivos, pequenos ruminantes.

\footnotetext{
*Corresponding author: Aleksandro Schafer da Silva

Departamento de Zootecnia do Centro de Educação Superior do Oeste,

Universidade do Estado de Santa Catarina - UDESC, Rua Beloni Trombeta

Zanin, 680-E, Bairro Santo Antônio, CEP 89815-630, Chapecó, SC, Brasil

e-mail: aleksandro_ss@yahoo.com.br
} 


\section{Introduction}

Neospora caninum is an obligate intracellular coccidian of the phylum Apicomplexa (DUBEY et al., 1988). Infection by $N$. caninum can cause a clinical disease called neosporosis, which is characterized mainly by abortion (LARSON et al., 2004), fetal death, reabsorption, mummification, autolysis or stillbirth; or by live birth but with adverse clinical signs; or by clinically normal birth but with chronic infection (DUBEY; LINDSAY, 1996).

Thus, neosporosis is a serious disease of cattle and dogs worldwide. However, clinical neosporosis has also been reported in sheep and goats (DUBEY, 2003). Serological surveys have so far been carried out in a few countries. Antibodies against $N$. caninum were reported in goats in Sri Lanka (NAGULESWARAN et al., 2004), Argentina (MOORE et al., 2007), Brazil (FARIA et al., 2007) and Poland (CZOPOWICZ et al., 2011). In order to confirm the diagnosis relating to abortion in goats, molecular techniques have been used in some Italian studies, in which presence of $N$. caninum was associated with aborted fetuses in 2 out of 23 animals (8.7\%), from PCR (MASALA et al., 2007).

Goats are economically important in many countries, including Brazil, where this species is a valuable source of meat and milk for humans, particularly in the northeastern region, where $93.7 \%$ of the goats are concentrated (IBGE, 2012). Low animal productivity is often caused by a lack of information on disease control, and, in this regard, there is a severe lack of information about neosporosis in goats. Some studies have reported occurrences of seropositive goats in different Brazilian states, such as Bahia (UZÊEDA et al., 2007), São Paulo (MODOLO et al., 2008), Rio Grande do Norte (LIMA et al., 2008) and Alagoas (ANDERLINI et al., 2011). However, in the state of Santa Catarina, there are still no studies on neosporosis in goats. Therefore, the objective of this study was to assess the seroprevalence of and determine the risk factors for $N$. caninum in serum samples from goats in two geographical regions of the state of Santa Catarina, Brazil.

\section{Materials and Methods}

\section{Animal sampling}

In this study, blood samples were obtained from 654 goats in 57 municipalities in the western and mountain regions of the state of Santa Catarina (SC), Brazil (Figure 1), between August 2012 and March 2013. The sample distribution was in accordance with the goat herd distribution in SC. This study quantified municipalities with the highest numbers of goats, with an expected prevalence of $25 \%$, error of $3.2 \%$ and confidence level of $95 \%$ (OPAS, 1979).

The animals were randomly chosen so as to represent different stages of development and weight, as well as different productive

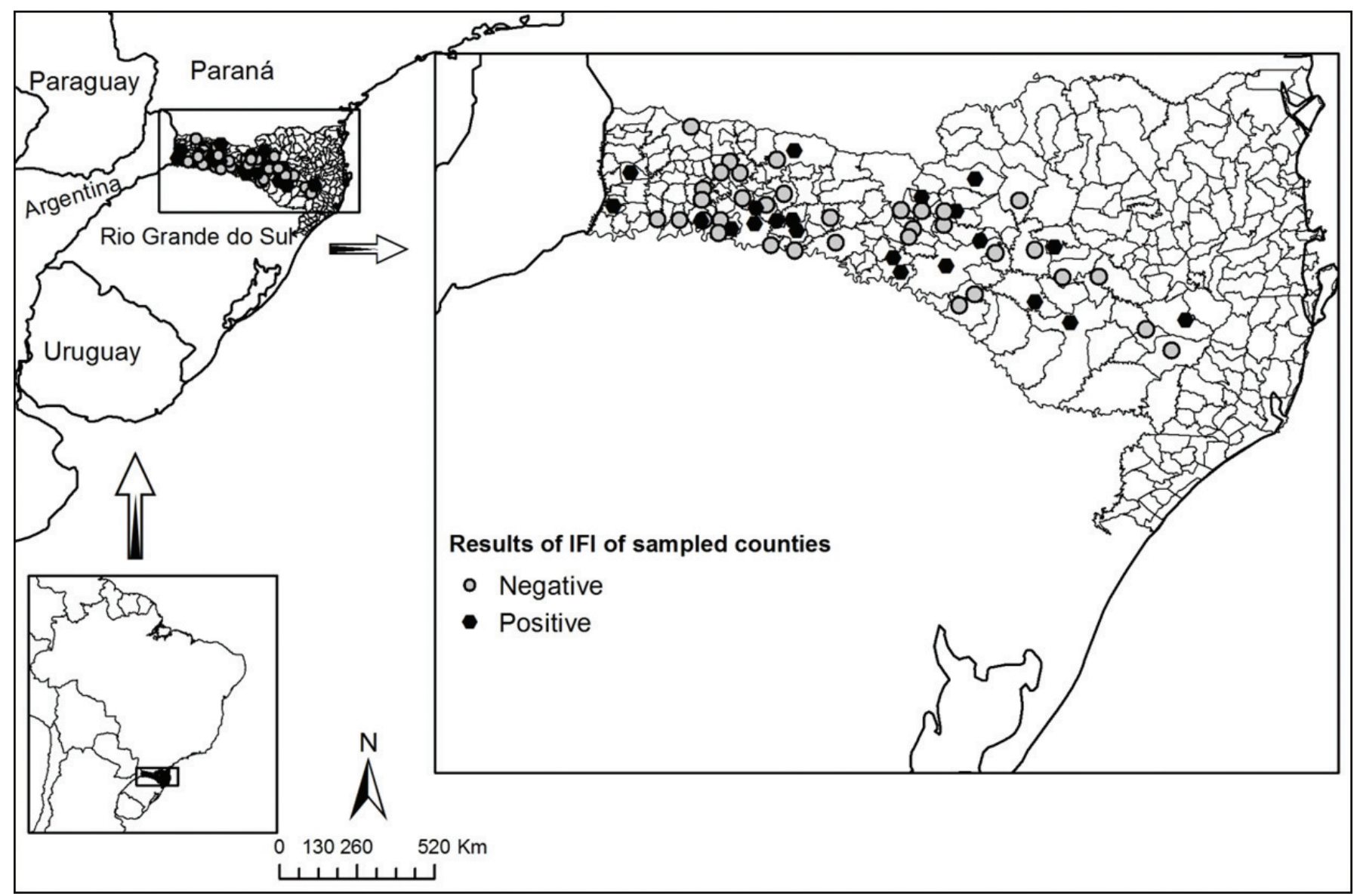

Figure 1. Map of the epidemiological distribution of neosporosis positivity $(\mathrm{n}=30)$ out of 654 goats in Santa Catarina State, Southern Brazil. 
purposes (meat and milk). The animals were manually restrained and blood samples were collected by venipuncture (Vacutainer ${ }^{\circledR}$ ) from the external jugular vein. Blood samples were placed in tubes without anticoagulant and kept under refrigeration $\left(10^{\circ} \mathrm{C}\right)$. They were then centrifuged and the serum was frozen $\left(-20^{\circ} \mathrm{C}\right)$ until analysis.

\section{Serological tests}

The separated serum was processed by means of the indirect immunofluorescence assay (IFA) in order to detect anti- $N$. caninum (CONRAD et al., 1993). Briefly, $N$. caninum tachyzoites (NC-1 strain) grown in Vero cells were used as antigens. Anti-IgG goat antibodies conjugated with fluorescein were used as the secondary antibody (LOCATELLI-DITTRICH et al., 2006). Samples were considered to be positive when fluorescence occurred on the entire tachyzoite surface and negative when fluorescence was absent or only apically present. Known positive and negative samples were used as controls (PARÉ et al., 1995). The serum samples were tested for antibodies at a dilution of 1:50. Positive samples were tested up to the maximum dilution at which was possible to detect antibodies against the protozoa.

\section{Epidemiological survey}

Information about each herd was obtained through direct interviews with the producers in order to ascertain the real situation of these animals on the farms, as well as to identify risk factors for neosporosis. The following questions were asked regarding each animal: breed (non-breed, Boer or Anglo), sex (male or female), age (between 6 months and 1 year, or more than 1 year), diet (with concentrate or without concentrate), water source (natural, river, well water or piped water), reproductive issues (yes or no), neurological issues (yes or no), type of production (milk, meat or mixed) and contact with dogs (yes or no).

\section{Statistical analysis}

The data generated by the survey and by the serological tests for neosporosis were recorded and analyzed using the R statistical software, version 2.13.1. Cross-tabulation was performed and descriptive statistics were produced. The variables were first screened based on the results from the response variable of the IFA test (positive or negative); variables with large amounts of missing data $(>10 \%)$ and limited variability $(<20 \%)$ were not included in the logistic regression model. The remaining variables were used in a univariate analysis using the chi-square test or Fisher's exact test, and variables with $P<0.25$ were selected for inclusion in the logistic regression model. Subsequently, all the screened variables were subjected to association analysis. The non-collinear variable was $>0.7$. Interactions between all pairwise variables suitable for the final model were examined and, if significant $(P<0.05)$, were subjected to further analysis. Subsequently, the selected variables $(n=4)$ were included in the multivariable model (breed, diet, reproductive issues and type of production). The multivariable variance models, using binary logistic regression, were built using a manual forward method; and each remaining variable was added to the best previous model, as selected using the Akaike information criterion (AIC) and the Bayesian information criterion (BIC). Finally, a backward elimination step was used, thus resulting in a final model in which only variables with $P<0.05$ were retained. Confounding effects were investigated by checking changes in estimated points for the variables that were kept in the model. Changes in parameters that were estimated as $>25 \%$ were considered to be confounding factors: age was found to be a potential confounding factor and, thus, it was controlled for during the regression. The goodness-of-fit of the final model was tested using the Hosmer-Lemeshow method (DOHOO et al., 2009), the discrimination power was tested by means of the ROC curve and the classification matrix to measure the performance (DOHOO et al., 2009), and The Wald $\chi 2$ test was used to determine significance of each model as a whole as well as to determine significance of individual $\beta$ coefficients.

\section{Results}

\section{Serological analysis}

Out of the 654 samples analyzed, only 30 were seropositive for $N$. caninum by means of IFA, thus corresponding to a prevalence of $4.59 \%$ distributed in different locations/farms (Figure 1). The positive samples had titers ranging from 1:50 to 1:6400 (Figure 2).

\section{Risk factors for neosporosis infection}

There was a weak correlation between age and neosporosis infection; however, this was identified as a confounding factor, given that it changed the parameter estimates for some of the selected variables by more than $25 \%$, which consequently forced it into the model.

In the univariate analysis, the goat breed, diet provided for the animals, contact with domestic dogs, reproductive issues like abortion and type of production practiced by the farm were

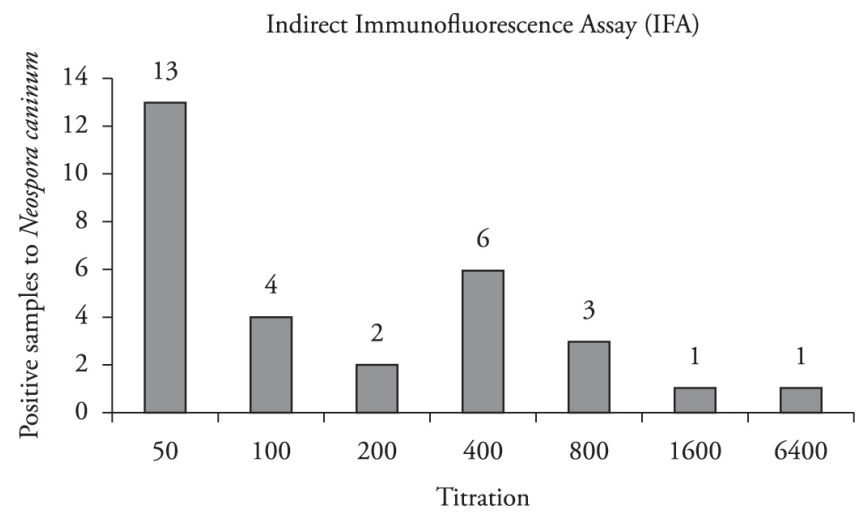

Figure 2. Results of serological tests and their respective titers in positive goats $(n=30)$ for Neospora caninum from two geographical regions of the state of Santa Catarina, Brazil. 
significantly associated with neosporosis infection $(P<0.25)$ (Table 1). Nevertheless, for the multivariate variance model, one selected confounding variable was forced into the model, since it changed the parameter estimated, as described above, and because of prior knowledge: in the light of analyses on the diet used and presence of reproductive issues, animal age was considered to be a risk factor. Reproductive issues found on the farms present a casual risk that was 2.94 times greater than in the absence of such issues (95\% CI: 1.45-5.47) and the farms that provide concentrate feed as a supplement to the animals presented a risk that was 2.94 greater than when no supplement was provided ( $95 \% \mathrm{CI}$ : 1.17-7.34), with regard to the risk of neosporosis (Table 2). The model fitted the

Table 1. Univariate analysis of risk factors for Neospora caninum infection in 654 goats from Southern Brazil.

\begin{tabular}{|c|c|c|c|c|}
\hline Variables & No. of animals & Frequency (\%) & $P$-value & RR (IC 95\%) \\
\hline \multicolumn{5}{|l|}{ Neosporosis } \\
\hline Breed & 654 & & 0.10 & \\
\hline Not breed & & 70 & & $0.53(0.28-1.00)$ \\
\hline Boer & & 27 & & $0.57(0.10-3.28)$ \\
\hline Anglo & & 3 & & \\
\hline Sex & 654 & & 0.39 & \\
\hline Male & & 20 & & - \\
\hline Female & & 80 & & $0.62(0.25-1.53)$ \\
\hline Age & 654 & & 0.47 & \\
\hline 6 months -1 year & & 22 & & - \\
\hline >1year & & 78 & & $0.81(0.58-1.13)$ \\
\hline Diet & 654 & 52 & 0.03 & \\
\hline Without concentrate & & 48 & & $2.28(1.19-4.37)$ \\
\hline With concentrate & & & & - \\
\hline Water source & 654 & & 0.38 & \\
\hline Natural spring & & 53 & & $2.47(0.44-13.66)$ \\
\hline River & & 9 & & $0.73(0.37-1.43)$ \\
\hline Well water & & 30 & & $0.82(0.28-2.38)$ \\
\hline Tap water & & 8 & & - \\
\hline Reproductive issues & 654 & & 0.18 & \\
\hline Yes & & 23 & & $0.48(0.19-1.17)$ \\
\hline No & & 77 & & - \\
\hline Neurological issues & 654 & & 0.98 & \\
\hline Yes & & 4 & & $4.12 .93(0.00-\infty)$ \\
\hline No & & 96 & & - \\
\hline Type of production & 654 & & 0.08 & \\
\hline Milk & & 3 & & - \\
\hline Meat & & 87 & & $3.82(1.03-14.07)$ \\
\hline Both & & 10 & & $6.00(1.06-33.66)$ \\
\hline Contact with dogs & 654 & & 0.03 & \\
\hline Yes & & 71 & & - \\
\hline No & & 29 & & $0.67(0.35-1.27)$ \\
\hline
\end{tabular}

Table 2. Final logistic regression analysis of the risk factors for Neospora caninum infection in 654 goats from Southern Brazil*.

\begin{tabular}{|c|c|c|c|}
\hline Variables & Estimate $(\beta)$ & $P$-value & RR (CI: 95\%) \\
\hline Intercept & 3.84 & $<0.001$ & $46.66(19.36-93.45)$ \\
\hline \multicolumn{4}{|l|}{ Confunding } \\
\hline Age & & 0.30 & \\
\hline 6 months -1 year & -0.52 & & $0.59(0.25-1.35)$ \\
\hline$>1$ year & - & & - \\
\hline \multicolumn{4}{|l|}{ Risk factors } \\
\hline \multicolumn{4}{|l|}{ Reproductive issues } \\
\hline Yes & 1.07 & 0.05 & $2.94(1.17-7.34)$ \\
\hline No & - & & - \\
\hline \multicolumn{4}{|l|}{ Type of diet } \\
\hline With concentrate & 1.03 & 0.01 & $2.82(1.45-5.47)$ \\
\hline Without concentrate & - & & - \\
\hline
\end{tabular}

${ }^{*}$ Roc curve $=66 \%$, Hosmer test $=\mathrm{p}=0.91$, Wald test: $\chi^{2}=9.4, \mathrm{df}=3, \mathrm{p}=0.024$. 
Table 3. Classification matrix for the prediction results of the multivariate analysis.

\begin{tabular}{cccc}
\hline & Predicted value & Correct classification \\
\hline Observed value & Positive & Negative & $63.33 \%$ \\
Positive & 19 & 11 & $70.03 \%$ \\
Negative & 187 & 437 & \\
\hline
\end{tabular}

data sufficiently well as demonstrated by the Hosmer-Lemeshow test $(P=0.91)$. The area under the curve (AUC) is 0.667 , with a $69.72 \%$ hit rate for classification (Table 3).

\section{Discussion}

This study provides the first report of $N$. caninum seroprevalence in goats in the state of Santa Catarina, Brazil. Our results showed that the $N$. caninum seroprevalence was around 5\% (4.59\%) among goats. According to the literature, neosporosis may be an important cause of abortion in goats (COSTA et al., 2012), and it may explain their low productivity rates (MASALA et al., 2007). Our results were close to what was reported by Bartova and Sedlak (2012), who found a seroprevalence of 6\% in goats in the Czech Republic. Antibodies against $N$. caninum were found in 6.4\%, 6.6\% and 9\% in Brazil (FARIA et al., 2007), Argentina (MOORE et al., 2007) and Poland (CZOPOWICZ et al., 2011), respectively. Thus, our results are quite similar to those mentioned above. The serological survey carried out by Moore et al. (2007) in Argentina provided important data, since Argentina is a country neighboring Brazil with similar geographic and climatic characteristics. Another interesting comparison is in relation to the prevalence study conducted by Faria et al. (2007) in the northeastern region of Brazil, the region with the highest concentration of goats (IBGE, 2012).

Dairy goats are more likely to have direct contact with reservoirs such as dogs, since they may come close to human homes, and also because the majority of the farms evaluated were of small sizes. Furthermore, this animal category (dairy goats) usually receives a diet rich in concentrates, which is an important risk factor for neosporosis that was observed in our study. The possible explanations for these findings might include inappropriate food storage (which was not investigated in this study) or direct contact with domestic animals, especially dogs. In comparing the univariate analyses on data regarding goat breed, diet, direct contact with dogs, reproductive failure (abortion) and production category, we found significant positive correlations $(\mathrm{P}<0.25)$. All these correlations are associated with infection by $N$. caninum.

Among the 57 municipalities surveyed, positive samples were found in 21 of them. This number shows the epidemiological importance of these findings in terms of the geographic distribution of neosporosis within the production cycle in this region, especially considering that there are difficulties in neosporosis control (REICHEL; ELLIS, 2006, 2008) and that vaccination and chemotherapy have only been identified as economically promising options, and not yet as safe and efficient (HÄSLER et al., 2006a, 2006b). Additionally, this serologically assessed region has a significant population of dairy cattle (IBGE, 2012), and some studies have shown that the prevalence is elevated in these animals (GOTTSTEIN et al., 1998; REICHEL 2000; BARTELS et al., 2006; WANG et al., 2010).

Reproductive problems on the farms represented a casual risk that was 2.94 times greater in the presence of these problems. It is well documented that in cattle, infection with $N$. caninum causes quite important reproductive problems, such as stillbirth and maternal infertility (MONNEY et al., 2011), and also, especially, epidemic and endemic abortion (BUXTON et al., 2002; DUBEY, 2003; DUBEY et al., 2007; MONNEY et al., 2011). However, regarding goats, some concerns regarding misdiagnosis and lack of correct diagnosis of neosporosis by local veterinarians still persist in Brazil. This might be partially explained by the close resemblance between Toxoplasma gondii, which is of high medical importance, and $N$. caninum, since these are closely related protozoa that are found in reproductive diseases (MONNEY et al., 2011). However, this issue was mitigated when Dubey et al. (1988) successfully isolated the parasite in the late 1980s.

Another important risk factor pointed out in the present study was direct contact between goats and dogs. On small farms, goats are usually housed together with other animals, like dogs, which can contaminate the environment with $T$. gondii and $N$. caninum oocysts (BARTOVA; SEDLAK, 2012). Horizontal transmission of $N$. caninum occurs through ingestion of tissue cysts, which is more likely to be relevant for carnivores, and through intake of food and water contaminated with sporulated oocysts (DUBEY et al., 2007). Based on our statistical analysis, the concentrate-based diet was considered to be a risk factor for neosporosis, which might be explained through situations in which dogs had access to the food storage facilities, or even to the places where goats were fed.

Our serological results were quite similar to those obtained from other studies throughout the world, showing relatively low positivity for $N$. caninum. However, our results show some very important casual risk factors such as reproductive problems, diet handling and free contact with dogs. Thus, it is possible to conclude that neosporosis is present, even at low serological levels, in the goat herds of the western and mountain regions of the state of Santa Catarina, Brazil, and is associated with some important risk factors. Because of the unfavorable characteristics of $N$. caninum infection, further epidemiological studies on neosporosis are always important.

\section{Ethical Approval}

Experimental protocol was approved by the Animal Welfare Committee of Universidade do Estado de Santa Catarina (UDESC) under number 1.15.13. 


\section{References}

Anderlini GA, Farias EB, Silva AM, Pinheiro JW Jr, Valença RMB, Anderlini GPOS, et al. Prevalência de anticorpos anti-Neospora caninum em caprinos no estado de Alagoas, Brasil. Vet Zootec 2011; 18(4): 583590.

Bartels CJ, Arnaiz-Seco JI, Ruiz-Santa-Quitera A, Björkman C, Frössling J, von Blumröder D, et al. Supranational comparison of Neospora caninum seroprevalences in cattle in Germany, The Netherlands, Spain and Sweden. Vet Parasitol 2006; 137(1-2): 17-27. PMid:16417972. http:// dx.doi.org/10.1016/j.vetpar.2005.12.016

Bartova E, Sedlak K. Toxoplasma gondii and Neospora caninum antibodies in goats in the Czech Republic. Vet Med 2012; 57(3): 111-114.

Buxton D, McAllister MM, Dubey JP. The comparative pathogenesis of neosporosis. Trends Parasitol 2002; 18(12): 546-552. http://dx.doi. org/10.1016/S1471-4922(02)02414-5

Conrad PA, Sverlow K, Anderson M, Rowe J, BonDurant R, Tuter $\mathrm{G}$, et al. Detection of serum antibody responses in cattle with natural or experimental Neospora infections. J Vet Diagn Invest 1993; 5(4): $572-$ 578. PMid:8286457. http://dx.doi.org/10.1177/104063879300500412

Costa HF, Stachissini AVM, Langoni H, Padovani CR, Gennari SM, Modolo JR. Reproductive failures associated with antibodies against caprine arthritis-encephalitis virus, Toxoplasma gondii and Neospora caninum in goats in the state of Sao Paulo, Brazil. Braz J Vet Res Anim Sci 2012; 49(1): 67-72.

Czopowicz C, Kaba J, Szalus-Jordanow O, Nowicki M, Witkowski L, Frymus T. Seroprevalence of Toxoplasma gondii and Neospora caninum infections in goats in Poland. Vet Parasitol 2011; 178(3-4): 339-341. PMid:21324599. http://dx.doi.org/10.1016/j.vetpar.2011.01.039

Dohoo IR, Martin W, Stryhn H. Veterinary epidemiologic researcho. Charlottetown: Atlantic Veterinary College; 2009.

Dubey JP, Carpenter JL, Speer CA, Topper MJ, Uggla A. Newly recognized fatal protozoan disease of dogs. J Am Vet Med Assoc 1988; 192(9): 1269-1285. PMid:3391851.

Dubey JP, Lindsay DS. A review of Neospora caninum and neosporosis. Vet Parasitol 1996; 67(1-2): 1-59. http://dx.doi.org/10.1016/S03044017(96)01035-7

Dubey JP. Review of Neospora caninum and neosporosis in animals. Korean J Parasitol 2003; 41(1): 1-16. PMid:12666725 PMCid:PMC2717477. http://dx.doi.org/10.3347/kjp.2003.41.1.1

Dubey JP, Schares G, Ortega-Mora LM. Epidemiology and control of neosporosis and Neospora caninum. Clin Microbiol Rev 2007; 20(2): 323-367. PMid:17428888 PMCid:PMC1865591. http://dx.doi. org/10.1128/CMR.00031-06

Faria EB, Gennari SM, Pena HFJ, Athayde ACR, Silva MLCR, Azevedo SS. Prevalence of anti-Toxoplasma gondii and anti-Neospora caninum antibodies in goats slaughtered in the public slaughterhouse of Patos city, Paraíba State, Northeast region of Brazil. Vet Parasitol 2007; 149(1-2): 126-129. PMid:17706359. http://dx.doi.org/10.1016/j. vetpar.2007.07.009

Gottstein B, Hentrich B, Wyss R, Thür B, Busato A, Stärk KD, et al. Molecular and immunodiagnostic investigations on bovine neosporosis in Switzerland. Int J Parasitol 1998; 28(4): 679-691. http://dx.doi. org/10.1016/S0020-7519(98)00006-X

Häsler B, Stärk KD, Sager H, Gottstein B, Reist M. Simulating the impact of four control strategies on the population dynamics of Neospora caninum infection in Swiss dairy cattle. Prev Vet Med 2006a; 77(3-4): 254-283. PMid:16962190. http://dx.doi.org/10.1016/j.prevetmed.2006.07.007

Häsler B, Regula G, Stärk KD, Sager H, Gottstein B, Reist M. Financial analysis of various strategies for the control of Neospora caninum in dairy cattle in Switzerland. Prev Vet Med 2006b; 77(3-4): 230-253. PMid:16982104. http://dx.doi.org/10.1016/j.prevetmed.2006.07.006

Larson RL, Hardin DK, Pierce VL. Economic considerations for diagnostic and control options for Neospora caninum-induced abortions in endemically infected herds of beef cattle. J Am Vet Med Assoc 2004; 224(10): 1597-1604. PMid:15154728. http://dx.doi.org/10.2460/ javma.2004.224.1597

Instituto Brasileiro de Geografia e Estatística - IBGE. SIDRA: Sistema IBGE de Recuperação Automática [online]. 2012 [cited 2014 Mar 3]. Available from: www.sidra.ibge.gov.br/bda/.

Lima JTR, Ahid SMM, Barrêto RA Jr, Pena HFJ, Dias RA, Gennari SM. Prevalência de anticorpos anti-Toxoplasma gondii e anti-Neospora caninum em rebanhos caprinos do município de Mossoró, Rio Grande do Norte. Braz J Vet Res Anim Sci 2008; 45(2): 81-86.

Locatelli-Dittrich R, Dittrich JR, Richartz RR, Gasino Joineau ME, Antunes J, Pinckney RD, et al. Investigation of Neospora sp. and Toxoplasma gondii antibodies in mares and in precolostral foals from Paraná state, Southern Brazil. Vet Parasitol 2006; 135(3-4): 215-221. PMid:16289863. http://dx.doi.org/10.1016/j.vetpar.2005.10.010

Masala G, Porcu R, Daga C, Denti S, Canu G, Patta C, et al. Detection of pathogens in ovine and caprine abortion samples from Sardinia, Italy, by PCR. J Vet Diagn Invest 2007; 19(1): 96-98. PMid:17459840. http:// dx.doi.org/10.1177/104063870701900116

Modolo JR, Stachissini AVM, Gennari SM, Dubey JP, Langoni H, Padovani CR, et al. Freqüência de anticorpos anti-Neospora caninum em soros de caprinos do estado de São Paulo e sua relação com o manejo dos animais. Pesq Vet Bras 2008; 28(12): 597-600. http://dx.doi.org/10.1590/ S0100-736X2008001200006

Moore DP, Yaniz MG, Odeón AC, Cano D, Leunda MR, Späth EAJ, et al. Serological evidence of Neospora caninum infections in goats from La Rioja Province, Argentina. Small Rum Res 2007; 73(1-3): 256258. http://dx.doi.org/10.1016/j.smallrumres.2006.10.019

Monney T, Debache K, Hemphill A. Vaccines against a major cause of abortion in cattle, Neospora caninum infection. Animals 2011; 1(3): 306-325. http://dx.doi.org/10.3390/ani1030306

Naguleswaran A, Hemphill A, Rajapakse RPVJ, Sager H. Elaboration of a crude antigen ELISA for serodiagnosis of caprine neosporosis: validation of the test by detection of Neospora caninum-specific antibodies in goats from Sri Lanka. Vet Parasitol 2004; 126(3): 257-262. PMid:15567589. http://dx.doi.org/10.1016/j.vetpar.2004.08.014

Organizacion Panamericana de la Salud - OPAS. Bioestatisica: procedimientos para estúdios de prevalencia por muestreo. Buenos Aires: OPAS; 1979. 
Paré J, Hietala SK, Thurmond MC. Interpretation of an indirect fluorescent antibody test for diagnosis of Neospora sp. Infection in cattle. J Vet Diagn Invest 1995; 7(2): 273-375. PMid:7619917. http://dx.doi. org/10.1177/104063879500700222

Reichel MP. Neospora caninum infections in Australia and New Zealand. Aust Vet J 2000; 78(4): 258-261. PMid:10840573. http://dx.doi. org/10.1111/j.1751-0813.2000.tb11751.x

Reichel MP, Ellis JT. If control of Neospora caninum infection is technically feasible does it make economic sense? Vet Parasitol 2006; 142(1-2): 23-34. PMid:16893606. http://dx.doi.org/10.1016/j. vetpar.2006.06.027
Reichel MP, Ellis JT. Re-evaluating the economics of neosporosis control. Vet Parasitol 2008; 156(3-4): 361-362. PMid:18620814. http://dx.doi. org/10.1016/j.vetpar.2008.06.002

Uzêda RS, Pinheiro AM, Fernández SY, Ayres MCC, Gondim LFP, Almeida MAO. Seroprevalence of Neospora caninum in dairy goats from Bahia, Brazil. Small Rum Res 2007; 70(2-3): 257-259. http://dx.doi. org/10.1016/j.smallrumres.2006.04.003

Wang C, Wang Y, Zou X, Zhai Y, Gao J, Hou M, et al. Seroprevalence of Neospora caninum infection in dairy cattle in northeastern China. J Parasitol 2010; 96(2): 451-452. PMid:19895158. http://dx.doi. org/10.1645/GE-2310.1 